\title{
Correction to: Thermal ageing of proteinaceous fouling layers during the growth phase
}

\author{
Lukas Schnöing $^{1}\left(\mathbb{D} \cdot\right.$ Wolfgang Augustin $^{1} \cdot$ Stephan Scholl ${ }^{1}$
}

Published online: 20 October 2021

๑) Springer-Verlag GmbH Germany, part of Springer Nature 2021

Correction to: Heat and Mass Transfer (2021) 57:333-341
https://doi.org/10.1007/s00231-020-02960-4

The article "Thermal ageing of proteinaceous fouling layers during the growth phase", written by Schnöing, L., Augustin, W. and Scholl, S., was originally published Online First without Open Access. After publication in volume 57, issue 2, page 333-341 the author decided to opt for Open Choice and to make the article an Open Access publication. Therefore, the copyright of the article has been changed to (C) The Author(s) 2021 and the article is forthwith distributed under the terms of the Creative Commons Attribution 4.0 International License, which permits use, sharing, adaptation, distribution and reproduction in any medium or format, as long as you give appropriate credit to the original author(s) and the source, provide a link to the Creative Commons licence, and indicate if changes were made. The images or other third party material in this article are included in the article's Creative Commons licence, unless indicated otherwise in a credit line to the material. If material is not included in the article's Creative Commons licence and your intended use is not permitted by statutory regulation or exceeds the permitted use, you will need to obtain permission directly from the copyright holder. To view a copy of this licence, visit http:// creativecommons.org/licenses/by/4.0/. Open access funding enabled and organized by Projekt DEAL.

The original article has been corrected.

Publisher's Note Springer Nature remains neutral with regard to jurisdictional claims in published maps and institutional affiliations.

The original article can be found online at https://doi.org/10.1007/ s00231-020-02960-4.

Wolfgang Augustin

w.augustin@tu-braunschweig.de

1 Institute for Chemical and Thermal Process Engineering,

Technische Universität Braunschweig, Langer Kamp 7,

38106 Braunschweig, Germany 